\title{
Multi Parameter Design in AI ML Framework for Balinese Calendar Knowledge Access
}

\author{
I Made Sukarsa ${ }^{1 *}$, Putu Wira Buana ${ }^{1}$, Urip Yogantara ${ }^{1}$ \\ ${ }^{1}$ Department of Information Technology, Udayana University, Bali, Indonesia \\ [e-mail: sukarsa@unud.ac.id] \\ * Corresponding author : I Made Sukarsa
}

Received July 4, 2019; revised Septebmer 10, 2019; accepted October 10, 2019; published January 31, 2020

\begin{abstract}
Balinese calendar is defined as a unique calendar system for combining solar-based and lunar-based system and assuming local system. It is considered as guidance of Balinese societies' activities management, starting from meeting arrangement, wedding ceremony, to religious ceremonies. Practically, it has developed in the form of printed Balinese calendar and electronic Balinese calendar, either web or mobile application. The core of the function is to find out the day with its various characteristics in the Balinese Calendar. In general, society usually asks the religious leader to find out the day in detail. The technology of NLP combined with models of pattern discoveries supports the arrangement of the interaction model in searching the good day in Balinese Calendar to equip the conventional searching system in the previous applications. This study will design a dialog model with AIML method in multi-parameter basis; therefore, the users will be dynamically able to use the searching content in various ways by chatting in similar with consulting to a religious leader. This model will be applied in a chatbot basis service in telegram machine. The addition of the context recognition section into 4 paterns has been successfully improve the ability of AIML to recognize input patterns with many criteria. Based on the testing with 50 random input patterns obtained a success rate of $92.5 \%$.
\end{abstract}

Keywords: Balinese Calendar, Wewaran, Dewasa Ayu, Chatbot, Natural Language Processing 


\section{Introduction}

Calendar is defined as the naming system of time period including day, month, year, and the others. The period naming might be based on the solar system such as the movement of the sun and the moon. Hindu society in Bali assumes Saka Calendar as the calendar system. Balinese Saka Calendar also provides access to the Hindu in finding out a day of piodalan and pedewasan.

Hindus in Bali generally use the printed Saka Calendar and it is used in traditionally. As the technology is developing, Balinese Calendar is modernized, for instance, a web basis Balinese Calendar has been discovered and can be accessed online. In addition, there is also Android basis Balinese Calendar, in which the users can access the Balinese Calendar in their smartphone.

The usage of Balinese Calendar is currently considered less interactive when the users would like to find out the red-letter day and dewasa ayu (certain days that is believed as good days in Bali). This problem has led the researcher to the solution of the more interactive application in order to have the society find an easier way of finding out a red-letter day and dewasa ayu.

Chabot is a program that interacts with users by using natural language [1, 2]. Chatbot is the most popular example and the most popular among the Human Computer Interaction (HMI) [3]. Chatbot can provide chatting access by either audio or textual method [4]. Chatbot is made for humans in order to get them believe that they are talking to human although they are actually talking to machine [5].

Based on that, chatbot can be used to find out a red-letter day or dewasa ayu in more convenient and more interactive way; therefore, this kind of chatbot, Calendar Bali chatbot, is designed to find out the day of piodalan, Balinese Hindus ceremony that is celebrated every six-month or year, and dewasa ayu.

To make dialogue can occur using a variety of everyday conversations with natural language, then AIML is used in this modeling. Because of the data search on the Bali calendar cannot be completed with 1 parameter, therefore in this study, AIML is designed to be able to work with multiple criteria that can be set dynamically.

\section{Related Work}

In 2014, Pradnyani developed the Balinese calendar in the platform of android, starting from calculating the Balinese calendar attributes or symbols such as wewaran, pawukon, sasih, and others. In the same year Suwintana also developed Balinese calendar in the platform of android that is able to provide information regarding wariga (calendar system in Balinese Hindu) such as wuku, wewaran, sasih, ingkel, panangggal, panglong, purnama, tilem and rerahinan, in which the data are stored in SQLite [6]. It has also been developed in the form of engine PL SQL in order to make it enable to provide service in term of application features development based on the users' needs [7].

Chatbot recently develops in various methods. In 2016, Saptaji tried to develop chatbot on the basis of pattern matching that uses SQL in matching the pattern stored in the database [8]. In 2017, Suryani developed the chatbot by AIML method in order to provide information regarding tourist destination or object in East Java [9]. In the same year, Kulkarni used Natural Language Processing and Machine Learning as a solution for bank customer information issues [10]. Natural Language Processing (NLP) is considered as the appropriate way in developing chatbot of Balinese calendar with dynamic multi-parameter. The most recent study 
tried to develop framework of which the name is ISONER in order to build access model in term of information system in the basis of chat with NLP [11] and it has been improved in order to handle advanced business service by building extended integrated module in the machine of PL SQL [12].

AIML models that work only with sentence pattern recognition or combined with steaming models, generally work without using parameters. Research conducted by [5, 13, 14] all focus on matching input patterns with master patterns that are stored on a knowledge base. A similar focus was also found in research on the use of AIML in the Indonesian language domain [9, 15]. Not yet found the application of AIML which includes the introduction of parameters as additional criteria in pattern matching, including in solving the problems of searching dewasa ayu on the Bali calendar.

\section{Literature Review}

\subsection{Definition of Saka-Bali Calendar}

Calendar is definend as a number of days and dates those are arranged as the guidance of periodic humans' activities. Hindus in Bali uses the calendar system of which the name is "Kalender Saka-Bali” or Saka-Bali Calendar. It is really important for society in Bali [16]. A year has 12 months, and they are called sasih [7].

Table 1. Sasih in Balinese Calendar

\begin{tabular}{|l|l|l|}
\hline No & Sasih & Gregorian Calendar \\
\hline 1 & Kasa & Juli-Agustus \\
\hline 2 & Karo & Agustus-September \\
\hline 3 & Katiga & September-Oktober \\
\hline 4 & Kapat & Oktober-November \\
\hline 5 & Kalima & November-Desember \\
\hline 6 & Kaenam & Desember-Januari \\
\hline 7 & Kapitu & Januari-Februari \\
\hline 8 & Kawulu & Februari-Maret \\
\hline 9 & Kasanga & Maret-April \\
\hline 10 & Kadasa & April-Mei \\
\hline 11 & Jyesta & Mei-Juni \\
\hline 12 & Sadha & Juni-Juli \\
\hline
\end{tabular}

A sasih in Saka-Bali Calendar covers 30 days. There 2 phases in a sasih, penanggal and pangelong. The day, 15 days before the full moon, is assumed as penanggal, and the day, 15 days before the new moon (tilem) is assumed as pangelong. The 12 sasih(s) of Saka-Bali Calendar are presented in Table 1. 


\subsection{Pawukon Calendar}

Pawukon is defined as an arithmethic calculation or arrangement in a calendar. A phase of pawukon consists of 210 days, and there are $30 w u k u(s)$ (week) in a pawukon [17]. The names of the pawukon(s) are presented in Table 2.

Table 2. Wuku in Balinese Calendar

\begin{tabular}{|l|l|l|l|}
\hline No & Named of Wuku & No & Named of Wuku \\
\hline 1 & Sinta & 16 & Pahang \\
\hline 2 & Landep & 17 & Krulut \\
\hline 3 & Ukir & 18 & Mrakih \\
\hline 4 & Kulantir & 19 & Tambir \\
\hline 5 & Tolu & 20 & Medangkungan \\
\hline 6 & Gumbreg & 21 & Matal \\
\hline 7 & Wariga & 22 & Uye \\
\hline 8 & Warigadean & 23 & Menail \\
\hline 9 & Julungwangi & 24 & Prangbakat \\
\hline 10 & Sungsang & 25 & Bala \\
\hline 11 & Dungulan & 26 & Ugu \\
\hline 12 & Kuningan & 27 & Wayang \\
\hline 13 & Langkir & 28 & Klawu \\
\hline 14 & Medangsia & 29 & Dukut \\
\hline 15 & Pujut & 30 & Watugunung \\
\hline
\end{tabular}

The word wuku or pawukuan derive from word buku or slice, of which the meaning is 'slice. A phase of wuku consists of 7 days, starting from redite (Sunday), soma (Monday), anggara (Tuesday), budha (Wednesday), wrespati (Thursday), sukra (Friday), and saniscara (Saturday) [7]. Most of the red-letter and ceremonial days of Hindu in Bali are based on the pawukon cycle [18].

\subsection{Wewaran}

Different from the international day that starts at 00.00 midnights, the day in Bali starts when the sun rises at 6.00 [18]. The grouping of day in international way is known as a week, which consists of 7 days in a week. Wewaran is the system of days-grouping in Saka Calendar [7]. There are 10 groups of wewaran, starting from 1 (ekawara), 2 (dwiwara), 3 triwara, 4 (caturwara), 5 (pancawara), 6 (sadwara), 7 (saptawara), 8 (astawara), 9 (sangawara), and 10 (dasawara). 
Table 3. Wewaran in Balinese Calendar

\begin{tabular}{|c|c|c|c|c|c|}
\hline No & $\begin{array}{l}\text { Name of } \\
\text { wewaran }\end{array}$ & $\begin{array}{l}\text { Name of the } \\
\text { day }\end{array}$ & No & $\begin{array}{l}\text { Name of } \\
\text { wewaran }\end{array}$ & $\begin{array}{l}\text { Name of the } \\
\text { day }\end{array}$ \\
\hline 1. & Ekawara & 1. Luang & 6. & Sadwara & $\begin{array}{l}\text { 1. Tungleh } \\
\text { 2. Aryang } \\
\text { 3. Urukung } \\
\text { 4. Paniron } \\
\text { 5. Was } \\
\text { 6. Maulu }\end{array}$ \\
\hline 2. & Dwiwara & $\begin{array}{l}\text { 1. Menga } \\
\text { 2. Pepet }\end{array}$ & 7. & Saptawara & $\begin{array}{l}\text { 1. Redite } \\
\text { 2. Soma } \\
\text { 3. Anggara } \\
\text { 4. Buda } \\
\text { 5. Wrespati } \\
\text { 6. Sukra } \\
\text { 7. Saniscara }\end{array}$ \\
\hline 3. & Triwara & $\begin{array}{l}\text { 1. Pasah } \\
\text { 2. Beteng } \\
\text { 3. Kajeng }\end{array}$ & 8. & Astawara & $\begin{array}{l}\text { 1. Sri } \\
\text { 2. Indra } \\
\text { 3. Guru } \\
\text { 4. Yama } \\
\text { 5. Ludra } \\
\text { 6. Brahma } \\
\text { 7. Kala } \\
\text { 8. Uma }\end{array}$ \\
\hline 4. & Caturwara & $\begin{array}{l}\text { 1. Sri } \\
\text { 2. Laba } \\
\text { 3. Jaya } \\
\text { 4. Menala }\end{array}$ & 9. & Sangawara & $\begin{array}{l}\text { 1. Dungu } \\
\text { 2. Jangur } \\
\text { 3. Gigis } \\
\text { 4. Nohan } \\
\text { 5. Ogan } \\
\text { 6. Erangan } \\
\text { 7. Urungan } \\
\text { 8. Tulus } \\
\text { 9. Dadi }\end{array}$ \\
\hline 5. & Pancawara & $\begin{array}{l}\text { 1. Umanis } \\
\text { 2. Paing } \\
\text { 3. Pon } \\
\text { 4. Wage } \\
\text { 5. Kliwon }\end{array}$ & 10. & Dasawara & $\begin{array}{l}\text { 1. Pandita } \\
\text { 2. Pati } \\
\text { 3. Suka } \\
\text { 4. Duka } \\
\text { 5. Sri } \\
\text { 6. Manuh } \\
\text { 7. Manusia } \\
\text { 8. Raja } \\
\text { 9. Dewa } \\
\text { 10. Raksasa }\end{array}$ \\
\hline
\end{tabular}

\subsection{The Utility of the Balinese Calendar System}

Balinese society is considered as a cultural society those are based on values and philosophies of Hindu [19]. The Hindus have a philosophy of which the name is Tri Hita Karana, the harmony of the relationship among human beings, humans and environment, and humans and God. Paying attention to the good day when doing activities is the way to keep harmony [20]. 
Table 4. Ceremonial Days and Dewasa Ayu

\begin{tabular}{|c|c|}
\hline Ceremonial Days & Wuku/Wewaran/Sasih \\
\hline Pagerwesi & $\begin{array}{l}\text { Saptawara = Buda, Pancawara = Kliwon dan } \text { Wuku }= \\
\text { Sinta }\end{array}$ \\
\hline Tumpek Landep & $\begin{array}{l}\text { Saptawara = Saniscara, Pancawara = Kliwon dan } \\
\text { Wuku = Landep }\end{array}$ \\
\hline Galungan & $\begin{array}{l}\text { Saptawara = Buda, Pancawara }=\text { Kliwon dan } \text { Wuku }= \\
\text { Dungulan }\end{array}$ \\
\hline Kuningan & $\begin{array}{l}\text { Saptawara = Saniscara, Pancawara = Kliwon dan } \\
\text { Wuku = Kuningan }\end{array}$ \\
\hline Saraswati & $\begin{array}{l}\text { Saptawara = Saniscara, Pancawara = Umanis dan } \\
\text { Wuku = Watugunung }\end{array}$ \\
\hline Nyepi & Penanggal 1 Sasih Kadasa \\
\hline Siwalatri & Pangelong 14 Sasih Kapitu \\
\hline Dewasa Ayu for Married & $\begin{array}{l}\text { saptawara = soma, budha, wrespati,sukra } \\
\text { sasih }=\text { katiga, kapat, kalima, kapitu, kadasa } \\
\text { penanggal }=1,2,3,5,7,10,13 \\
\text { avoid } \\
\text { 1. kajeng kliwon, } \\
\text { 2. wuku = wariga, pujut, menahil, warigadean, } \\
\text { pahang, prangbakat, } \\
\text { 3. pasah }\end{array}$ \\
\hline $\begin{array}{c}\text { Dewasa Ayu for Cutting } \\
\text { Down Trees }\end{array}$ & 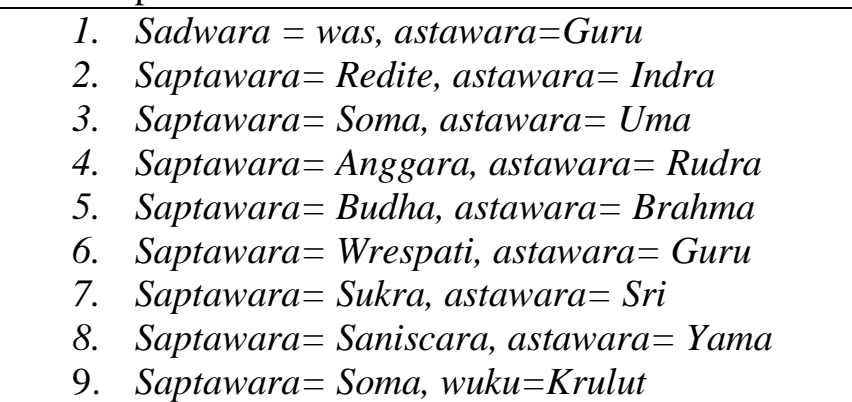 \\
\hline
\end{tabular}

Every aspect of social and cultural activities of Balinese people is considered using the Balinese Calendar. It is also guidance in determining the days of activities such as Hindu ceremonial day, religious ceremonial day in the temples, good days in terms of agriculture, farming, fishery affairs, building a house, wedding, and others [18]. Every aspect of social and cultural activities of Balinese people is considered using the Balinese Calendar. It is also guidance in determining the days of activities such as Hindu ceremonial day, religious ceremonial day in the temples, good days in terms of agriculture, farming, fishery affairs, building a house, wedding, and others [15]. Those all are based on considering the arrangement of Pawukon, Wewaran, Sasih. Some ceremonial days and dewasa ayu(s) are presented in Table 4. 


\subsection{AIML Model}

The components of the AIML are presented in the Figure. Artificial Intelligence Markup Language (AIML) is the sequel of the Extensible Markup Language (XML) that is established for creating an artificial chat. AIML basis Chatbot is easily configurated and easy in term of its use [21]. AIML consists of groups of patterns and responses used to find out responses of every comments, questions, and utterances given [9]. The parts of AIML are presented in Fig. 1.

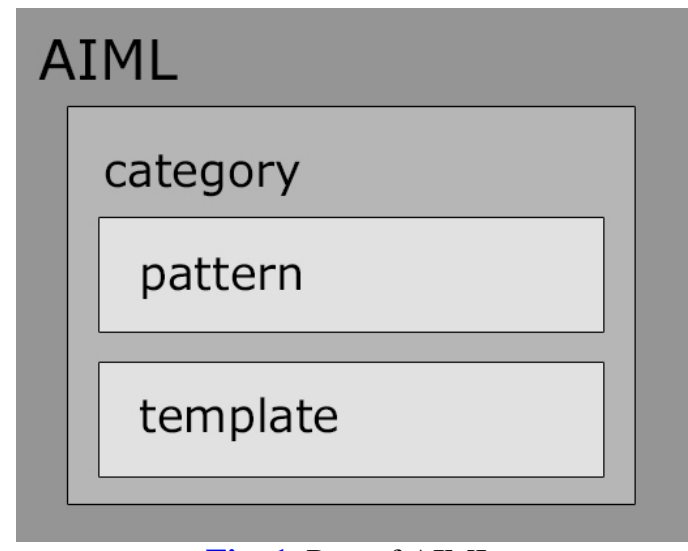

Fig. 1. Part of AIML

a. AIML

Tag indicating the beginning and final AIML document

b. Category

Category is the basic unit of knowledge. At least, category consists of two elements of AIML, pattern, and template.

c. Pattern

Pattern is used to make simple patterns that are expected to correspond to the users' input.

d. Template

Template determines the responses based on the corresponding pattern of the users' input.

\section{Design System}

\subsection{Chatbot Architecture}

Chatbot wariga information with this natural language processing approach provides the users access to ask for information regarding ceremonial days and dewasa ayu in Saka-Bali Calendar. The users can communicate in natural language regarding information of wariga that is implemented in the application of Telegram. The general description of wariga information chatbot is presented in Fig. 2. 


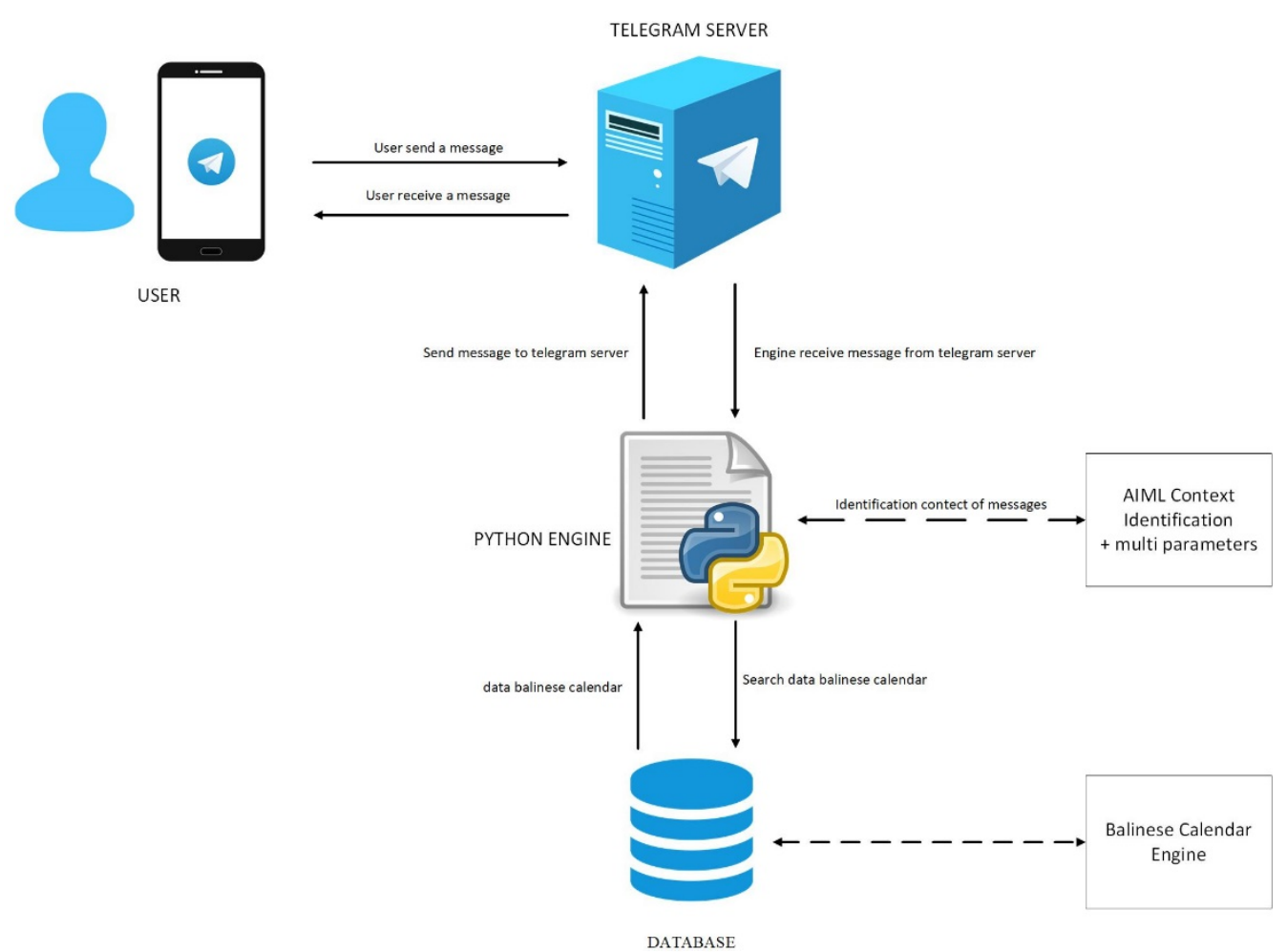

Fig. 2. General Description of The System

a. The user sends a message or asks for a question via Telegram by the username of info_wariga_bot.

b. Engine Python will receive message from the user, and it will be stored in the database.

c. The stored message will be processed by using NLP in order to recognize the context of the question.

d. The information searching is processed based on the users' message and the contexts of the message or question.

e. Engine Python will respond by providing answer or information to the user

The working principle and relationship of some basic AIML blocks with the addition of multi parameters can be explained in the input design in tables 4 to 7 and the flowchart in Fig. 2.

\subsection{Design Input of Chatbot}

Chatbot is designed to respond to a variety of messages sent by the users. The variety designed consist of descriptions regarding a ceremonial day, ceremonial day/ dewasa ayu without parameter and with multi-parameter searched, and ceremonial days/ dewasa ayu(s) asked in a message.

The first pattern is to ask for a description or information regarding a ceremonial day. It is presented in Table 5. 
Table 5. Pattern of Ceremonial/Red-letter Day Description

\begin{tabular}{|l|l|}
\hline Pattern & Example \\
\hline \multirow{4}{*}{ Question word + ceremonial/red-letter day } & Apa itu galungan? \\
\cline { 2 - 2 } & Kamu tau apa itu Nyepi? \\
\cline { 2 - 2 } & Deskripsikan tentang hari raya nyepi \\
\cline { 2 - 2 } & $\begin{array}{l}\text { Tolong berikan deskripsi tentang hari raya } \\
\text { Saraswati }\end{array}$ \\
\hline
\end{tabular}

Users are also able to search or find out a ceremonial day or good day in running certain activities as presented in Table 6.

Table 6. Pattern of Searching Dewasa Ayu/ Ceremonial Day without Parameter

\begin{tabular}{|c|c|}
\hline Pattern & Example \\
\hline \multirow{3}{*}{$\begin{array}{l}\text { Question word of time + } \\
\text { ceremonial/red-letter day }\end{array}$} & Kapan nyepi? \\
\hline & Kamu tau kapan hari raya galungan? \\
\hline & Carikan saya hari raya kuningan dong! \\
\hline \multirow{3}{*}{$\begin{array}{l}\text { ceremonial/red-letter day }+ \text { question word of } \\
\text { time }\end{array}$} & Galungan tanggal berapa? \\
\hline & Hari siwalatri kapan ya? \\
\hline & Apa kamu tahu, hari raya pagerwesi kapan? \\
\hline
\end{tabular}

A parameter can modify the ceremonial day or good day searching process. This parameter includes ekawara, dwiwara, triwara, caturwara, pancawara, sadwara, saptawara, astawara, sangawara, dasawara, wuku, months, and years as presented in Table 7.

Table 7. Pattern of Searching Dewasa Ayu/Hari Raya with Parameter

\begin{tabular}{|c|c|}
\hline Pattern & Example \\
\hline \multirow{3}{*}{$\begin{array}{l}\text { Question word of time }+ \\
\text { ceremonial/red-letter day }+ \text { paremeter }\end{array}$} & Tanggal berapa galungan tahun 2020? \\
\hline & $\begin{array}{l}\text { Kapan hari baik untuk menikah tahun } 2021 \text { bulan } \\
\text { november hari senin atau selasa? }\end{array}$ \\
\hline & Carikan saya hari purnama saat kajeng kliwon! \\
\hline \multirow{3}{*}{$\begin{array}{l}\text { parameter + ceremonial/red-letter day + } \\
\text { question word of time }\end{array}$} & tahun 2021 nyepinya kapan? \\
\hline & $\begin{array}{l}\text { Bulan desember 2020, hari baik untuk ngaben } \\
\text { kapan ya? }\end{array}$ \\
\hline & $\begin{array}{l}\text { Tahun } 2020 \text { yang bukan kliwon kapan saja hari } \\
\text { purnamanya? }\end{array}$ \\
\hline \multirow{3}{*}{$\begin{array}{l}\text { ceremonial/red-letter day }+ \text { parameter }+ \\
\text { question word of time }\end{array}$} & Purnama kadasa kapan ya? \\
\hline & $\begin{array}{l}\text { Hari baik untuk menikah pada sasih kadasa tahun } \\
2022 \text { hari jumat tanggal berapa? }\end{array}$ \\
\hline & $\begin{array}{l}\text { Dewasa untuk menebang pohon wuku Sinta kapan } \\
\text { ya? }\end{array}$ \\
\hline \multirow{3}{*}{$\begin{array}{l}\text { parameter + question word of time + } \\
\text { ceremonial/red-letter day }\end{array}$} & Tahun 2021 kapan siwalatri? \\
\hline & $\begin{array}{l}\text { Bulan Januari bukan hari Senin kapan dewasa ayu } \\
\text { untuk membangun rumah? }\end{array}$ \\
\hline & $\begin{array}{l}\text { Hari senin, selasa, atau rabu tanggal berapa hari } \\
\text { baik untuk menikah? }\end{array}$ \\
\hline
\end{tabular}


Users can find out more than one ceremonial day/ dewasa ayu with its parameter via message while the searching process as presented in Table 8.

Table 8. Pattern of Multi Ceremonial Days/ Dewasa Ayu Searching

\begin{tabular}{|l|l|}
\hline Pattern & Example \\
\hline $\begin{array}{l}\text { Question word of time + } \\
\text { ceremonial/red-letter day (1) + paremeter (1) }\end{array}$ & $\begin{array}{l}\text { kapan galungan tahun 2020, tumpek landep } \\
\text { bulan juni, dewasa menikah hari jumat? }\end{array}$ \\
\cline { 2 - 2 } $\begin{array}{l}\text { + ceremonial/red-letter day (2) + paremeter } \\
(2)+\text { ceremonial/red-letter day (n) + } \\
\text { paremeter (n) }\end{array}$ & $\begin{array}{l}\text { Tanggal berapa dewasa membangun rumah } \\
\text { bulan januari hari senin, hari baik menikah } \\
\text { tahun 2020, dan hari raya kuningan? }\end{array}$ \\
\hline $\begin{array}{l}\text { ceremonial/red-letter day (1) + paremeter (1) } \\
\text { + ceremonial/red-letter day (2) + paremeter } \\
\text { (2) + ceremonial/red-letter day (n) + } \\
\text { paremeter (n) + question word of time }\end{array}$ & $\begin{array}{l}\text { galungan tahun 2020, tumpek landep bulan } \\
\text { juni, dewasa menikah hari jumat, kapan? }\end{array}$ \\
\cline { 2 - 2 } & $\begin{array}{l}\text { dewasa membangun rumah bulan januari hari } \\
\text { senin, hari baik menikah tahun 2020, dan hari } \\
\text { raya kuningan, tanggal berapa? }\end{array}$ \\
\hline
\end{tabular}

\subsection{Message Processing}

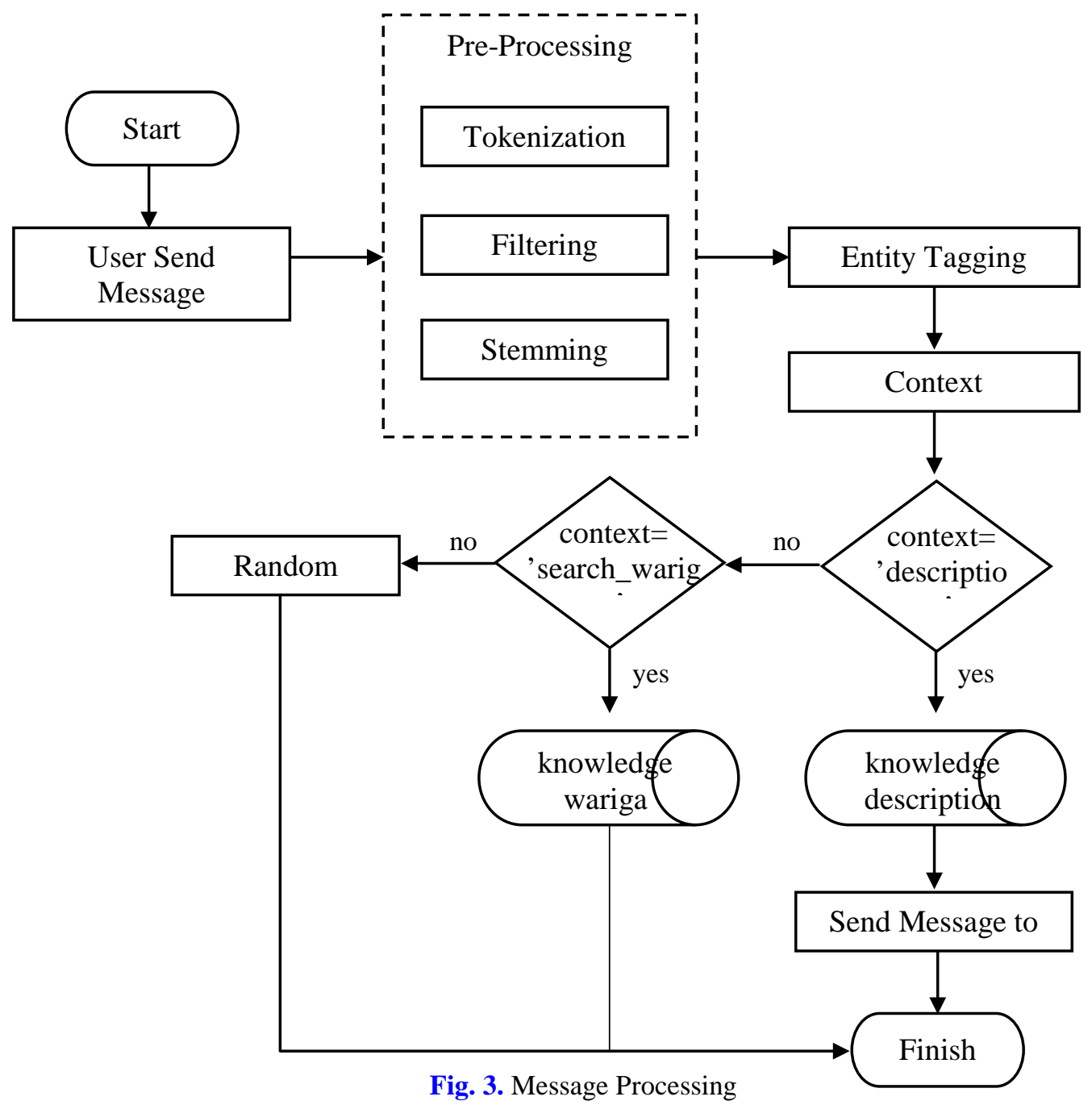


Fig. 3 represents the messages processing run by the engine python. The pre-processing will be previously running; it involves tokenization, filtering, and stemming. The tokenization process will process the password into word part known as a token. Filtering which uses the wordlist method will recognize the important parts or words of the token such as wuku, wewaran, ceremonial day, sasih, and others. The stemming process will process the word to be a root word by omitting suffixes containing algorithm of Nazief and Adriani. Each word then will be labeled (tag) in order to identify the context of a message.

If the contexts take the form of description, data will be taken from the table of description in the database. If the context is considered as ceremonial day/ dewasa ayu searching result, data will be taken from the table of a calendar with its additional parameter. If the context of the message is unknown, there will be a random message "Mohon maaf, saya tidak mengerti" or "Sorry, I don't understand".

\section{Results and Analysis}

\subsection{Chatbot Interface}

Chatbot is designed with instant messaging Telegram. The users can start interacting with the bot after adding bot to their contact with username @info_wariga_bot. Fig. 4 presents the bot searching process that has been running.

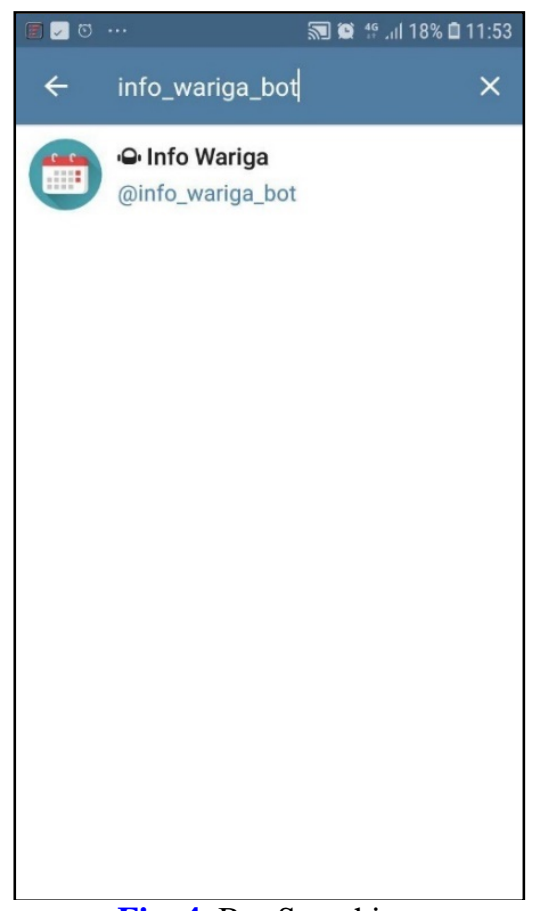

Fig. 4. Bot Searching

In order to get access in communicating with a bot, the Telegram users can process the searching by inputting the username of the bot in the application of search bar. The users can start communicating after clicking "start interface pesan". The bot can provide information regarding the ceremonial day/ dewasa ayu asked by the users as presented in Fig. $\mathbf{5}$. 


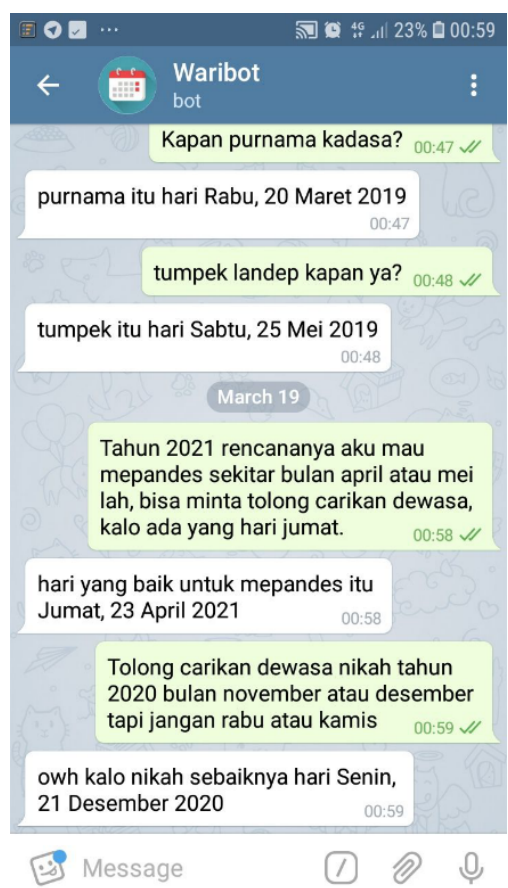

Fig. 5. Chatbot Interface

The users will interact with bot by this interface, in which the users will send and receive messages. Chatbot will reply to the message based on the pattern determined.

\subsection{Testing Scenario}

10 respondents will take part in the test, those are chosen from society who use this Balinese Calendar. Each respondent will get chances to ask 5 questions for each category including ceremonial day description, ceremonial day/ dewasa ayu searching without parameter, ceremonial day/ dewasa ayu searching with parameter, and multi ceremonial day/ dewasa ayu searching. Each user is asked to make questions for each pattern as explained in Tables 4 to 7 according to the language habits of each respondent. Because respondents are selected from various education classes that reflect variations in potential real users in the field, therefore, the resulting combination of questions is expected to represent the opportunities for questions that can arise in daily practice. The result of the test recapitulation is presented in Table $\mathbf{9}$.

Table 9. Recapitulation of The Testing

\begin{tabular}{|l|c|c|c|c|c|c|c|c|}
\hline \multirow{2}{*}{ Nama Responden } & \multicolumn{2}{|c|}{ Pattern I } & \multicolumn{2}{c|}{ Pattern II } & \multicolumn{2}{c|}{ Pattern III } & \multicolumn{2}{c|}{ Pattern IV } \\
\cline { 2 - 9 } & c & i & c & i & c & i & c & i \\
\hline Responden 1 & 5 & 0 & 5 & 0 & 5 & 0 & 3 & 2 \\
\hline Responden 2 & 5 & 0 & 4 & 1 & 5 & 0 & 4 & 1 \\
\hline Responden 3 & 5 & 0 & 5 & 0 & 4 & 1 & 5 & 0 \\
\hline Responden 4 & 4 & 1 & 3 & 2 & 4 & 1 & 5 & 0 \\
\hline Responden 5 & 5 & 0 & 5 & 0 & 5 & 0 & 1 & 4 \\
\hline Responden 6 & 5 & 0 & 5 & 0 & 5 & 0 & 5 & 0 \\
\hline Responden 7 & 5 & 0 & 5 & 0 & 5 & 0 & 5 & 0 \\
\hline
\end{tabular}




\begin{tabular}{|l|l|l|l|l|l|l|l|l|} 
Responden 8 & 5 & 0 & 5 & 0 & 5 & 0 & 5 & 0 \\
\hline Responden 9 & 5 & 0 & 5 & 0 & 5 & 0 & 4 & 1 \\
\hline Responden 10 & 5 & 0 & 4 & 1 & 5 & 0 & 5 & 0 \\
\hline
\end{tabular}

Table 9 shows the recapitulation of the chatbot. There are some mistakes found in the responses of the chatbot in each pattern. There is 1 mistake in patter I. There are 4 mistakes in pattern II. There are 2 mistakes in pattern III. There are 8 mistakes in pattern IV. The result of the recapitulation is presented in a bar graph in Fig. 6.

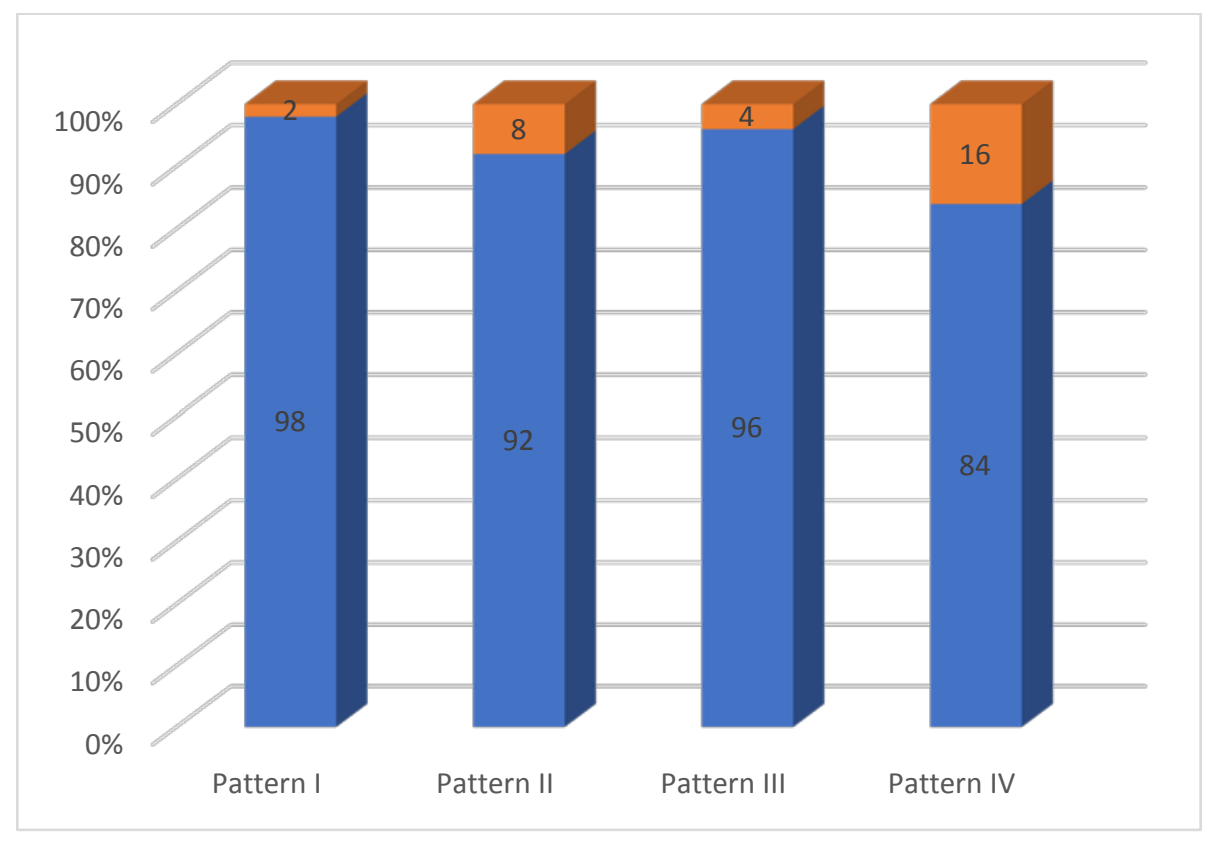

Fig. 6. Chart of the Testing

Each pattern in chatbot has been tested. In descriptive pattern, it is found $98 \%$ correct answers from 50 questions. In the pattern of the ceremonial day searching without parameter, there are $92 \%$ correct answers from 50 questions. In the pattern of ceremonial searching with parameter, there are $96 \%$ correct answers from 50 questions. In multi ceremonial days/ dewasa ayu searching there are $84 \%$ correct answers from 50 questions. If averaged on each pattern, $92.5 \%$ of the answers from the bot are correct.

\subsection{Response Error on Chatbot}

There are several causes that cause the chatbot not to respond correctly. The first cause is specific description questions, for example asking what god is worshiped at the ceremony. The next cause is an unknown ceremonial day. The third cause is an unspecified time statement, such as next month, next two years, etc. The next cause is to ask how many days to the ceremony. The next cause is to ask the month of the ceremony. The last cause is an abbreviation of a word. 
Table 10. Response Error on Chatbot

\begin{tabular}{|l|l|}
\hline \multicolumn{1}{|c|}{ Cause } & \multicolumn{1}{c|}{ Example } \\
\hline Specific description questions & a. Apa makna memotong babi dan ayam \\
& bada hari penampahan galungan? \\
& bewa apa yang dipuja pada hari raya \\
\hline Unknown ceremonial days & a. Kapan dilaksanakannya hari raya \\
& b. Kapan diadakannya mecaru? \\
\hline Unspecified time statement & a. Kapan galungan 2 tahun lagi? \\
\hline How many days to ceremony & b. Kapan purnama bulan depan? \\
\hline Asking the month of ceremony & a. $\quad$ Berapa hari lagi hari raya purnama? \\
\hline Abbreviation & a. Kpn galungan? \\
\hline
\end{tabular}

Solutions that can be offered for the first cause is add a specific knowledge base of a ceremonial days. Likewise the cause of the second error is by completing the knowledge base of the ceremonial days. Solutions for the third, fourth and fifth problems is create a new pattern to handle the message. The last problem for abbreviations can be to use the N-Gram algorithm.

\subsection{Comparison with the N-Gram Algorithm}

The engine that was created will be compared with the N-Gram algorithm. The test is done in description pattern (I). The result of the test is presented in Table $\mathbf{1 1 .}$

Table 11. Testing on N-Gram Algorithm

\begin{tabular}{|l|c|c|c|}
\hline \multirow{2}{*}{ Messages } & \multicolumn{3}{c|}{ Threshold } \\
\cline { 2 - 4 } & $\mathbf{0 . 1}$ & $\mathbf{0 . 5}$ & $\mathbf{0 . 7}$ \\
\hline Apa itu Galungan? & correct & correct & incorrect \\
\hline $\begin{array}{l}\text { Kamu tau apa itu hari raya } \\
\text { galungan? }\end{array}$ & correct & incorrect & incorrect \\
\hline $\begin{array}{l}\text { Tolong berikan deskripsi } \\
\text { mengenai hari raya galungan? }\end{array}$ & correct & incorrect & incorrect \\
\hline $\begin{array}{l}\text { Jelaskan pada saya tentang hari } \\
\text { raya galungan? }\end{array}$ & correct & incorrect & incorrect \\
\hline
\end{tabular}




\begin{tabular}{|l|c|c|c|}
\hline $\begin{array}{l}\text { Beri tahu aku deskripsi hari raya } \\
\text { galungan dong! }\end{array}$ & correct & incorrect & incorrect \\
\hline $\begin{array}{l}\text { Tolong berikan pengertian } \\
\text { mengenai hari raya galungan }\end{array}$ & correct & incorrect & incorrect \\
\hline $\begin{array}{l}\text { Deskripsikan tentang hari raya } \\
\text { galungan }\end{array}$ & correct & incorrect & incorrect \\
\hline $\begin{array}{l}\text { Tolong deskripsikan apa sih hari } \\
\text { raya nyepi itu? }\end{array}$ & correct & incorrect & incorrect \\
\hline $\begin{array}{l}\text { Berikan deskripsi tentang hari } \\
\text { raya nyepi dong! }\end{array}$ & correct & incorrect & incorrect \\
\hline $\begin{array}{l}\text { Segera berikan saya deskripsi } \\
\text { mengenai apa itu hari raya nyepi }\end{array}$ & correct & incorrect & incorrect \\
\hline
\end{tabular}

The result of the test using NGram algorithm are $100 \%$ on threshold $0.1,10 \%$ on threshold 0.5 , dan $0 \%$ on threshold 0.7 . This value is smaller than using the AIML method with multi parameters. This method also has drawbacks that require many patterns so it will be difficult to do a multi-parameter search.

\section{Conclusion}

Chatbot that is designed in Telegram instant messaging uses the method of Natural Language Processing; it can provide information regarding the ceremonial day and dewasa ayu based on Balinese Calendar. AIML with NLP method becomes a good choice when the users send dynamic message. NLP supports the development of the chatbot in terms of receiving multi parameters input in ceremonial days/dewasa ayu such as ekawara, dwiwara, triwara, caturwara, pancawara, sadwara, saptawara, astawara, sangawara, dasawara, wuku, months, and years.

The addition of several matching parameters to the NLP algorithm enables the recognition capabilities of AIML to support pattern recognition with various criteria that can be determined dynamically according to needs. Of the 50 questions tested in each pattern, an average percentage of success was obtained at $92.5 \%$. Further research is needed to enable the discovery of answers according to the user's wishes when AIML produces many options for 1 pattern.

\section{References}

[1] A. Vichare, A. Gyani, Y. Shrikhande, and N. Rathod, "A chatbot system demonstrating Intelligent Behaviour using NLP," International Journal of Advanced Research in Computer Engineering \& Technology (IJARCET), vol. 4, no. 10, pp. 3783-3785, 2015. Article (CrossRef Link)

[2] R. Shah, SiddhantLahoti, and P. L. K, "An Intelligent Chat-bot using Natural Language Processing," International Journal of Engineering Research, vol. 6, no. 5, pp. 281-286, 2017. Article (CrossRef Link) 
[3] A. Khanna, B. Pandey1, K. Vashishta, K. Kalia, B. Pradeepkumar, and T. Das, "A Study of Today's A.I. through Chatbots and Rediscovery of Machine Intelligence," International Journal of u- and e-Service, Science and Technology, vol. 8, no. 7, pp. 277-284, 2015.

Article (CrossRef Link)

[4] E. Haller and T. Rebedea, "Designing a Chat-bot that Simulates an Historical Figure," in Proc. of presented at the 19th International Conference on Control Systems and Computer Science, Bucharest, Romania, 2013. Article (CrossRef Link)

[5] N. Mhatre, K. Motani, M. Shah, and S. Mali, "Donna Interactive Chat-bot acting as a Personal Assistant," International Journal of Computer Applications, vol. 140, pp. 6-11, 2016. Article (CrossRef Link)

[6] K. Suwintana and P. M. Prihatini, "PERANCANGAN APLIKASI KALENDER BALI PADA SMARTPHONE BERBASIS ANDROID," SEMINAR NASIONAL SAINS DAN TEKNOLOGI, 2014. Article (CrossRef Link)

[7] I. M. D. M. Putra, I. M. Sukarsa, D. P. Githa, and I. W. K. Wijaya, "A Reusable Balinese Calendar Engine," Journal of Theoretical and Applied Information Technology, vol. 96, no. 1, pp. 267-278, 2019. Article (CrossRef Link)

[8] B. Setiaji and F. W. Wibowo, "Chatbot Using A Knowledge in Database Human-to-Machine Conversation Modeling," in Proc. of presented at the 7th International Conference on Intelligent Systems, Modelling and Simulation, Bangkok, Thailand, 2016. Article (CrossRef Link)

[9] D. Suryani and E. L. Amalia, "Aplikasi Chatbot Objek Wisata Jawa Timur Berbasis AIML," SMARTICS Journal, vol. 3, no. 2, pp. 47-57, 2017. Article (CrossRef Link)

[10] C. S. Kulkarni, A. U. Bhavsar, S. R. Pingale, and P. S. S. Kumbhar, "BANK CHAT BOT - An Intelligent Assistant System Using NLP and Machine Learning," International Research Journal of Engineering and Technology, vol. 4, no. 5, pp. 2374-2377, 2017. Article (CrossRef Link)

[11] I. M. Sukarsa, I. K. G. D. Putra, N. P. Sastra, and L. Jasa, "A New Framework for Information System Development on Instant Messaging for Low Cost Solution," TELKOMNIKA, vol. 16, no. 6, pp. 2799-2808, 2018. Article (CrossRef Link)

[12] I. M. Sukarsa, I. K. G. D. Putra, N. P. Sastra, and L. Jasa, "Modification of ISONER Framework as Enterprise Service Bus to Build Consultation Robot Using External Engine," International Journal of Engineering and Emerging Technology, vol. 3, pp. 123-128, 2018. Article (CrossRef Link)

[13] B. AbuShawar and E. Atwell, "ALICE Chatbot: Trials and Outputs," Computacion y Sistemas, vol. 19, pp. 625-632, 2015. Article (CrossRef Link)

[14] A. Dole, H. Sansare, R. Harekar3, and S. Athalye, "Intelligent Chat Bot for Banking System," International Journal of Emerging Trends \& Technology in Computer Science (IJETTCS), vol. 4, pp. 49-51, 2015. Article (CrossRef Link)

[15] K. T. Wirawan, I. M. Sukarsa, and I. P. A. Bayupati, "Balinese Historian Chatbot using Full-Text Search and Artificial Intelligence Markup Language Method," I.J. Intelligent Systems and Applications, vol. 11, pp. 21-34, 2019. Article (CrossRef Link)

[16] I. A. P. Pradnyani, "Aplikasi Kalender Bali Berbasis Mobile Application pada Android Platform," Merpati, vol. 2, pp. 106-117, 2014. Article (CrossRef Link)

[17] I. P. C. Prawira, G. M. A. Sasmita, and I. P. A. Bayupati, "Pengembangan Aplikasi Kalender Saka Bali pada Sistem Operasi Machintos," Merpati, vol. 3, pp. 58-67, 2015. Article (CrossRef Link)

[18] G. Ginaya, "The Balinese Calendar System: From Its Epistemological Perspective to Axiological Practices," International Journal of Linguistics, Literature and Culture, vol. 4, 2018.

[19] I. W. Swandana, G. Mahendrayana, and L. G. E. Wahyuni, "Pemaknaan Tanda dalam Ala Ayuning Dewasa Berdasarkan Wewaran pada Kalender Caka Bali," Seminar Nasional Riset Inovatif, pp. 88-92, 2017. Article (CrossRef Link)

[20] I. M. Suarjana, I. G. P. Suharta, and I. G. N. Japa, "Etnomatematika Sistem Kalender Bali," Seminar Nasional Riset Inovatif, pp. 177-182, 2014. Article (CrossRef Link)

[21] S. V. Doshi, S. B. Pawar, A. G. Shelar, and S. S. Kulkarni, "Artificial Intelligence Chatbot in Android System using Open Source Program-O," International Journal of Advanced Research in Computer and Communication Engineering, vol. 6, pp. 816-821, 2017. Article (CrossRef Link) 


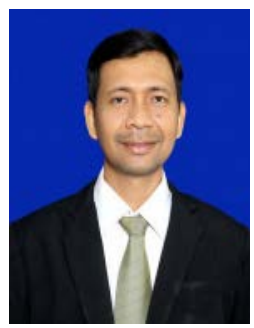

I Made Sukarsa obtained his Doctoral Degree in Udayana University in 2019. He currently works as a lecturer in the Department of Information Technology University of Udayana. His research interests are Natural Language Processing, Integration System, Data Warehouse, Middleware, and Information Technology Governance.

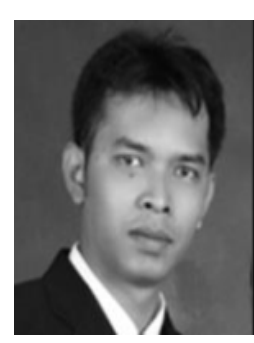

Putu Wira Buana, he obtained his Master Degree in The Science of Applied Electronics at Brawijaya University in 2007. He currently works as a lecturer in the Department of Information Technology University of Udayana. His research interests are Emerging Technology, And Industry Application.

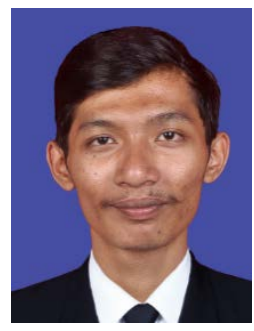

Urip Yogantara obtained his Bachelor Degree in Departement of Information Technology at Udayana University. He currently works as IT Consultant and Programmer. His research interests are Natural Language Processing and Industry Application 